\title{
Heavenly Orchestrations
}

\section{The World of the Legendary Pìrs of Bengal}

I make obeisance to the spectacle of creation, its parts strung together like a necklace.

I pay my deepest respects to Mohämmad, Beloved of God. With undivided attention I salute Satya Närāyan, descended (avatār) in the Kali Age.

At the command of Allla, he took birth in the world of men, wondrously engendered from two different lineages.

He emerged from the womb of the unwed Sandhyāvati to tend the affairs of the kingdom of Mälañcā.

His right hand grips a staff,

a mesmerizing flute sparkles in his left.

His head is smothered with matted locks,

a brilliant dot blazes across his forehead;

a golden sacred thread hangs from his shoulder,

and a linked chain belt winds around his waist,

body swathed in a gleaming ochre-colored cloth.

He wanders back and forth from one region to another,

dressed in the garb of an ascetic sannyāsī,

assuming any number of guises and forms.

Who can fathom the wizardry of this holy pir:

one life-giving heart, two distinct physical forms,

two different names, for two different communities.

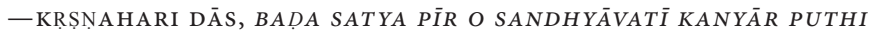




\subsection{THE TALE OF THE BIRTH OF SATYA PİR}

Let our story begin with the narrative of the birth of the saint found in The Great Story of Satya Pìr and the Virgin Girl Sandhyāvatī. ${ }^{1}$ With that laudatory opening and much much more, the author declares the plentiful benefits of paying respect to this $s \bar{u} p h \bar{\imath}^{2}$ saint. After a rather urgent final personal disclaimer, the hagiographer segues into the story, which begins with a curious exchange among several of the significant occupants of heaven.

Through his mysterious power, Bhagavān Satya Nārāyaṇ is my life's breath. With my mind focused, I pay obeisance to the feet of my guru. On my head I place and honor the names of my father and mother as I make a thousand prostrations. All of them together enable me to swim to the farther shore of this ocean of existence. May my guru helmsman safely guide me across; may he keep my failures of memory at bay, and grant me wisdom. May the fourteen syllables come together just right to create each metrical line of verse, and enable this hobbled poet to hurdle the mountain. Like so many prolix brähmaṇs, may my writing hand wax like the moon, after which, waving a fan palm frond, may I calm and cool all those gathered to hear.

Among the thousands of people present in this vast audience, Satya Pìr comes to those who call, whether orphans without means or those simply in need of direction. Should all present sing their praises publicly, Satya Pīr will send their troubles far away. When people serve him with respect, offering the custom due, Satya Pïr can become the refuge of every human being. May he grant me the power to sing this song of revelation, so that you too may spread its message. If my public audience

1. Kṛșṇahari Dās, Baḍ satya pīr o sandhyāvatì kanyār puthi (Kalikātā: Nuruddīn Āhmad at Gaosiyā Lāibrerī, n.d.). What follows is a synopsis mixed with translated sections of the first thirty-nine of the printed text's two hundred twenty pages. The undated manuscript copy in my possession suggests a mid- to late-eighteenth-century composition, while, based on the layout, font, spellings, and metrical markers, the undated printed text has the appearance of a late-nineteenth-century production. I am indebted to the late Ābul Kālām Mohāmmad Jākāriyā in Dhaka for allowing me to copy the manuscript of the text from his personal collection.

2. Süphi is of course roughly equivalent in sound and meaning to the word Sufi in English, but as will become apparent, the semantic field of this and other terms does not always perfectly map. I have chosen to transliterate all terms as they are written in Bangla. The names and epithets of all characters in the stories, as well as technical terminology, will be rendered in transliteration that reflects the orthography and in most cases the pronunciation of the Bangla in which it is written. Importantly, God will be rendered as it is written in Bangla, Āllā, rather than the more familiar Allāh used in transcriptions of Arabic and Persian. Other terms such as phakir or phakir, jäban or jaban, oli (rather than auliy $\bar{a}$ ), or $g \bar{a} j \bar{i}$ (rather than ghāzi), and so forth will become easily familiar. The point is to disrupt the assumption of the reader that the terms in Bangla automatically signal the same semantic range they invoke in Arabic, Persian, Sanskrit, or other languages. The differences in both denotation and connotation can at times be profound, so the transliteration of the Bangla term will serve to remind the reader that the conceptual world of Islam, while shared historically and transnationally, is neither uniform nor consistent through time or space. Please also consult the "Conventions Regarding Transliteration and Nomenclature" in the front matter for more of the problems of transliteration and the use of English terms. 
feels that my song falls flat, I will be humbled, yet even by that uncommonly ordinary exercise of dharma, I may still help rescue many among them.

You [Satya Pīr] are a saint (oli). If this tale embarrasses you among the society of prophets $(n a b \bar{i})$, then I shall abandon your company and escape to some faraway place; may you have Âllā and the Prophet (nabī) eat my head, binding me head-to-toe a hundred times over. With just your two bare hands you are able to subdue Prithivi, the Earth Herself. Like a hundred expert warriors armed with bows, accompanied by thousands upon thousands of horsemen of all colors and stripes, you destroy one king's kingdom in order to put another king in his place.

The old king, Mādhāi, ${ }^{3}$ his favored [queen] Priyāvatī, and their two princes, Saamsundar and Dāmodar, were among those so chosen. Priyāvatī constantly fussed over her husband, ministering to his needs in both body and spirit. While the king, indeed, did have many fine qualities and served to protect dharma, as a rule he proved extremely mean-spirited toward phakirs. Whenever one of the phakirs of God Khodā appeared in the city, Mādhāi would chain him around the neck and imprison him in a cell. If the phakir was deemed to cast an evil eye, he would be blown to bits by the royal cannons; then for thirteen days the king would drink only water and eat only rice in penance. Numerous vaiṣnavi $\bar{s}^{4}$ and ascetic sannyāsīs were always in attendance; they performed ritual sevā and $p \bar{u} j \bar{a}$ worship, for which Mādhāi conferred gifts of great value.

The angel Jibril observed, "O Āllā, Guardian and Nourisher, this king who reigns in the Kali Age is a terrible sinner. He slays God-loving people (momin) and chops them to pieces. When he sees one of your phakirs, he has him shackled round the neck, and the phakìr can be heard crying out for help in a loud voice, 'Āllā, Āllā!' Untold numbers of phakirs have been securely detained in this way. Tell me Nirāñjan, Stainless One, why are they not being protected?"

Āllā spoke, "Give me a solution, a plan, my beloved Prophet (nabī). Whom might we dispatch, to descend and serve as my witness ( $g \bar{a} o y \bar{a} r$ )?"

The Apostle (rachul) replied, "Āllā, Great Protector, Satya Pīr should descend as the avatār in this Kali Age. There is in paradise (bhest) a certain Cāndbibī, whose beauty is typical of a heavenly celestial nymph, a færie (hurparī). Send her down to take birth from the belly of that king's consort Priyāvatī. From the womb of that

3. He would later be called by the epithet maidānav or mayadānav, the Demon King. It is unlikely a coincidence that his name invokes that of one of the two willfully belligerent antagonists of Kṛ̦na Caitanya (1486-1533) in Nabadvīp, Jāgāi and Mādhāi, who were redeemed by the intervention of two of Caitanya's closest companions, Nityānanda and Gadādhar, and subsequently became devout vaiṣnavs; see Vṛndāvan Dās, Caitanya bhāgavat, edited with Bengali commentary "Nitāikaruṇākallolinī ṭikā" by Rādhāgovinda Nāth (Kalikātā: Sādhanā Prakāśanī, 1373 Bs [ca. 1966], 2.13. For an already somewhat dated translation of the tale, see Tony K. Stewart, trans., "The Rescue of Two Drunkards," in The Religions of India in Practice, ed. Donald S. Lopez, Jr., (Princeton: Princeton University Press, 1995), 375-88.

4. The way vaiṣnavi is used in this text, it appears to be grammatically incorrect, but seemingly apposite in construction to sannyāsī, that is, a male vaișnav or a vairāgī rather than a female worshiper of Kṛṣna or Caitanya. If we read female worshiper, then it likely signals that women of the king's family and court were highly learned, for vaiṣnav women were often employed by the wealthy to educate daughters in reading, writing, poetics, and so forth. 
comely virgin girl will Satya Pīr be born. He shall spring from the mixing of two different communities ( $k u l)$ and will serve both publicly."

Āllā responded, "What a brilliant plan you have suggested, Apostle (rachul). But when he takes on a mortal human form, he must not enter into any marriage. Anything that happens after that, you report to me. Whatever shape he assumes in the ocean of worldly existence, he must retain my name."

Mohāmmad replied, "So it is decided; that is the strategy we will pursue. I will send Jibril to Cāndbibî.”

And so the angel (pherestā) went to call on the Bibì.

While he was sitting there, exactly what kind of karma had Mohāmmad brought into play? For in the gateway to heaven he fashioned a venomous serpent with a physical bodily form, and then he had a frog sent as its meal.

Meanwhile Jibril called out, "Bibì, come! Your presence is requested. The honorable Prophet is calling you for a special cause. He would be most pleased were you to come right away," [which of course she did].

When she arrived and came upon Mohāmmad's conjured scene, Cāndbibī was stopped dead in her tracks.

The frog was weeping bitterly since it had fallen into the mouth of the serpent. It cried out, "Āllā, please forestall my imminent death!" The frog immediately appealed to her, "Bibī, hear my prayer. Please save me from the jaws of this serpent! If you do not, I am finished. I can only appeal to Âllā for justice."

But the serpent countered, "Listen, Bibì, consider my position. By the decree of the God of Fate, Bidhātā, has this meal been sent me. I have not eaten in more than a month. If the frog is destined to die to provide my meal, it is by the proclamation of Āllā.”

The situation seemed intractable as each argued his case. Examining the conundrum from every angle, Cāndbibī reasoned through her options and finally resolved to act. Once decided, she promptly snatched the frog from the jaws of the snake and released it into the waters.

Thoroughly confounded, the serpent declared, "Cāndbibī, you have always been a paragon of virtue, so how could you steal the food right out of my mouth?" The snake continued his lamentation: "Because of your actions, I have been denied my life-sustaining meal."

[Cāndbibī] wasted no time in leaving and hurried on to the court of Āllā, presented herself, and made obeisance. Bibī spoke, "Pāk Nirāñjan, Pure and Stainless One, for what reason have you summoned me?"

Āllā replied, "Listen Bibī, here is why: you must go down to the demonic king Maidānav's home as the daughter of his queen, Rājarānī Priyāvatī. When you have taken birth in their home, you will become the royal princess Sandhyāvatī and from your womb will Satya Pīr take birth. I will come down as my own witness and become the embodied descent (avatār) of truth (satya)."

Cāndbibī replied, "Please listen, Āllā, Stainless One. How will I, a færie, be able to endure the excruciating pain of child bearing? In order for there to be a live birth, a fetus must grow in a woman's womb for ten months. ${ }^{5}$ In the dark of night, the house 
reverberates with her desperate and painful cries, 'Help! Save me!' The agony emanating from her womb is not to be endured by the frail likes of me. I am incapable of reproducing as that princess. Please do forgive me, Āllā, for challenging this. How and why am I to descend, Āllā? Why must I suffer the consequences of this singular entry to the world of ordinary human existence? Can you not please send someone else to the demon king's home?"

The Prophet replied, "You must go by the terms decreed. You will be gracious toward the Master and you will not disobey."

Turning then to Mohāmmad, Cāndbibī pleaded, "Please listen! What offense have I committed for you to condemn me to a mortal existence? Only those who are flawed and sinful must undergo birth as mortals. Who can send me to the land of mortals to become a jäbanā?"'

By then the weakening snake, near death, had managed to catch up and wasted no time in lodging his complaint. "By what right could Cāndbibī have interfered and stopped me from eating? After more than a month I finally managed to land a frog morsel from the Dāmodar River. But Bibī plucked it right out of my mouth and sent it flying back to the deep." And with that pitiable lament, the now completely starved snake convulsed, writhed on the ground, and gave up its life.

[Mohāmmad then pointed out to Bibī], "This sin alone is sufficient to send you to hell. Only when you are born into a human clan will that sin and misery be atoned. After thirty-six years will your transgression be expiated."

As she listened to his words, Bibì lamented bitterly, "In the name of Āllā, what am I supposed to admit about this ersatz transgression of karma? I did not know what to do and for this ambiguous, if not deceptive, infraction you are going to dispatch me to the land of the mortals, to be touched, to be handled by a husband who comes from another social group $(j a \bar{t} i)$ ? I will become infamous in the whole of heaven."

The Prophet replied, "You will become the daughter of the king. But who has decreed that you are to be married? Whether for fame or infamy-that accrues to me. You are imagining miseries for no good reason. What Âllā brings about is for his own satisfaction and reasons. Now you must go and enter into the world of mortals."

Krṣnahari Dās shares this conversation in accomplished meter. May the hero Satya Pìr fulfill your heart's desire.

Listen brothers to this gratifying tale. No one can fathom what Khodā does. What is sanctioned and what is nullified, or the way what is previously approved becomes prohibited-who can comprehend the full extent of divine power? Who can reckon what is $\sin (p \bar{a} p)$ or what is merit (punya) in the divine economy? Why a sinner is destined to suffer while another prospers, why a person dies in one house and another lives-no matter how hard one tries, no one can fully explain it. Each individual suffers both sinful and meritorious qualities, and according to those tendencies will an individual habitually return. If a sin be committed while in heaven, then a return

6. Feminine of jaban or jāban (from yavana, lit. Ionian). A general term to designate people not originally from the subcontinent, today nearly always glossed as Muslim, but more accurately should be construed as an ethnic marker. 
to the mortal world is in store. If a sin is committed in the world of mortals, then one falls into hell (dojakh). Listen carefully now to the natures of heaven and hell.

Has anyone actually seen heaven? What individual can speak of hell? As written in the Korān, there are seven hells. But what are the characteristics described by people who have witnessed heaven and hell? Listen carefully and I will tell you about heaven. Heaven is like the best of our worldly society-whether it is or is not, that is what people say. Just imagine, if you will, the one who enjoys the creature comforts, who gets to loll about on a fragrant bed of flowers, to be the one who sleeps in a house adorned with flower blossoms, and always eats ghee and honey. Who gets to own the horses? Who amasses and holds others' debts? Who becomes the merchant trader? He who has become king is the lord (iśvar) who takes the wealth of other people, the bounty of this earth, to enjoy for himself. It is said in the book that heaven is something just like that.

Now listen, good people, for now I will describe what is said about hell. Whether it is or is not, understand this is what people have authoritatively reported. No one there can see, like one who has fallen into the dark of a deep well. No one can discern whether it is night or day. Deaf and mute, not a sound can slip from anyone's mouth. One has neither legs nor arms, for all of one's limbs rot away. Fixated on begging for food, one must fast without end. To be mired in sin is to live at the foot of a scrub brush, scavenging as a dog or jackal. Understand that this is the nature of hell people describe.

Listen brothers all as I submit this before you. Focus your attention and listen to the pāncāli tale of the saint. ${ }^{7}$

Cāndbibì continues to complain, especially among her closest companions, at which point the entire mechanism for her birth is explained by Mohāmmad, including the precedent that forty bibis have previously been impregnated by flowers sent from heaven for the birth of special pìrs. So Cāndbibī descends, and Queen Priyāvatī duly becomes pregnant and gives birth to Sandhyāvatī, much to the joy of the king and his courtiers. A little more than twelve blissful years pass, and Sandhyāvatī blossoms into a stunning beauty. But one night she finds herself restless, inexplicably agitated.

Āllā has instructed Mohāmmad to interrupt Sandhyāvatī’s sleep and reveal to her through her dreams that she is actually Cāndbibī, descended from heaven to bear the phakìr Satya Pīr. Mohāmmad then explains how, with her hundred companions, she will take herself to bathe in the River Ennar. There, immersed in the waters while bathing, a flower will float toward her and her alone, and it will impregnate her.

But before they can put the plan into effect, they have to get Satya Pīr to agree to the terms and conditions.

Āllā said, "My dear Messenger (paygambar), please put our plan into play, for the demon king Mayadānav is truly evil. Whenever one of my phakìrs goes to Mālañcā, he ends up chained by the neck and thrown in jail. As a result, the number of heralds 
to my majesty is diminishing everywhere on earth. In what fashion will my beloved son-as-witness (bețā gāoyār) pulverize the king?"

The Prophet replied, "Revered Âllā-ji, you are the master of petitioners. There is no one who can fathom your miracle-working power. An ocean of mercy, you exercise dominion over the magic of creation $(m \bar{a} y \bar{a})$. In your sight, the demon king Mayadānav is no more than a speck of a sesame seed. When you send Satya Pīr, Truth itself (satya) will be instituted through his descent (avatār) - he will be born from the womb of Sandhyāvatī. By following this unique expedient, two separate goals will be achieved. When the witness descends to miserable Mālañcā, the God (devatā) of the hindu will be the pirr of the musalmān. He will demonstrate how to serve both communities $(\mathrm{kul})$. In the Kali Age, untold numbers of people are conversant with sin ( $p \bar{a} p)$, but when they worship Satya, the Truth, their enlightenment will be effected and your majesty and glory will spread throughout the world (samsār). When that end is reached, may you quickly return him to heaven."

Listening to this plan of action, Âllā was exceedingly pleased. The Stainless One, Nirañjan, called and spoke to Jibril. Āllā said, "Listen carefully, Jibril, to what I say. Go fetch Satya Pīr to my dwelling."

No sooner had he received the command than off he flew. He called on Satya Pīr and escorted him to the presence of Āllā. When Satya Pīr arrived, he offered his profound salutations, "Why have you summoned me, you who are the treasure trove for supplicants?"

Âllā responded, "You must go once more to the world of mortals. The demonic king Mayadānav of Mālañcā perpetrates a reign of endless tyranny. I want you to fly down quickly and assume the task of spreading the noble ritual of revering God $(\operatorname{sev} \bar{a})$. Once you have initiated that ritual service in the city of Mālañcā proper, ensure it is instituted in each and every home."

Because it was the Pure and Stainless One, Pāk Nirañjan, who uttered these words, Satya Pīr replied, "Āllā, I humbly submit to your request. By all means dispatch me to earth, but I must admit that I am very much afraid to undergo the torments of the womb."

Āllā replied, "You will not suffer any of the burning pains of the womb. You will not even be born initially as yourself [in human form], but reproduced as a clot of blood."

Satya Pīr said, "Āllā, you are the great protector of all, please go ahead and send me down to earth. Whatever form you have me take in this birth, I will always be singularly devoted to your feet. In the Kali Age, so many people exist in misery-may they obtain their hopes and desires when they encounter me! May they be released from their dire straits and attain an exalted state of dignity! But tell me, how precisely am I to alleviate this suffering?"

Nirañjan, the Stainless, answered, "Go to earth, and any time you need, simply remember me, and you will succeed."

With that, Satya Pīr responded, "Whenever I fall into trouble, I shall take your name and by that alone may you rescue me."

Hearing this, Âllā promised, "The moment you start to utter my name, your worries will cease. He whom I do not allow to die cannot be killed. You will never suffer death in that earthly river of mortal life. You cannot be drowned, you cannot be 
burned by fire. Even if the moon or the sun were to attack you, you would not suffer death."

Events follow the script as expected. When Sandhyāvatī and her friends splash in the river, Sandhyāvatī mysteriously refuses to come out of the water until she retrieves a most exquisite rose blossom. As it floats upstream, the flower will dodge and flee the grasp of any of the young women who reach for it, always pushing itself slightly out of reach-until, that is, it makes its way to Sandhyāvatī.

The flower suddenly washed into her hands. In a single movement, Sandhyāvatī picked up that special blossom and sniffed its perfume. She breathed Satya Pīr right into her body, and he lodged in her womb. The flower instantly lost its brilliance, lost all color, withered, and died. Suddenly feeling queasy, she hurled the now wilted flower to the ground, but the flower flew from earth up to heaven like [Mohāmmad] in the night journey (meyārāj).

Listen now to the rest of the story of Sandhyàvatī. She finished bathing, returned to her group, and headed back to the capital city. Sandhyāvatī, the unmarried princess sans prince, had gotten pregnant. Accepting the command of my guru, I endeavor to make public this tale where Satya Pìr will fulfill every person's heart's desire. I grovel a hundred times over in salutation at the feet of Satya Pìr, for it is at your command that Krṣnahari sings this song. ${ }^{9}$

The servants are incredulous and then aghast as they try to hide Sandhyāvatī's increasingly obvious pregnancy. Eventually one serving girl informs the queen, who laments the stain on the family name. Sandhyāvatī herself is understandably confused. "I am an unmarried princess. How can I have gotten pregnant when I have never lain with a man? I cannot fathom this strange situation, but whatever is born from my womb will send me to hell, to Yam's perdition." She reconstructs the events at the river and realizes that she was impregnated the moment she inhaled the fragrance of the flower. "I cannot fathom Khodā's staging of this event." ${ }^{10}$ Her mother seeks to have an abortifacient slipped into the goat's milk Sandhyāvatī drinks every evening, but Satya Pīr, neatly curled up in her womb as he is, divines her plan and calls on God to intervene. God, Satya Nārāyaṇ, sends Jibril, who communicates with Satya Pīr and, through the power of yogic scriptural utterances (àgam śabda), magically transforms the poison into a dense, sweet cream. The abortion never happens.

When Queen Priyāvatī is finally forced to tell the king, he goes crazy with all-too-predictable anger. He orders his constable to take Sandhyāvatī into the forest and abandon her. The constable is horrified, for it is too much like Rām banishing the pregnant Sìtā to the forest. But banish her he does, and so, after tearful leave-taking and anguish, into the forest they go. Sandhyāvatī is allowed to take two

\footnotetext{
8. Kṛ̣ṇahari Dās, 13-14.

9. Kṛ̣ṇ̣ahari Dās, 16.

10. Kṛṣṇahari Dās, 17.
} 
servants with her. On their way they cross the Nur River and go through Haripur, Dioḍi village, Lakṣmīpur, Jayantinagar, then Tripurā. Passing Kadalī Dikinī, they reach Nokāgrām. Jayantinagar is the village where Sandhyāvatī’s brother Sāmsundar lives, but she refuses to visit him out of shame. They pass Thakāgrām, Kalyāṇ town, Dāmihāt, Śan̉khapur, Sāpinī Pāpin̄ī, and finally Bajarāśahar, until Sandhyāvatī can go no further. She asks the constable to erect a shelter there, but he refuses, pushing her forward. Finally, he abandons her on the banks of the Begavatī River.

Sandhyāvatī and her two servants camp out under the canopy of a massive tree for seven days and nights. Finding no food, they fast. Not a soul appears. At night, terrified, they lie down, their stomachs growling in hunger. At night the tigers prowl and growl, scattering the frenzied deer in every direction. Wild boars, oxen, and all manner of beasts tramp through the forest around them. Finally a female and male tiger couple, drawn by the irresistible smell of human flesh, creep forward for the kill.

But Sandhyāvatī spoke first. "O tigress, I am emotionally overwhelmed, for I have come to the forest pregnant. Clamp your jaws around me and eat me so that you may put an end to my burning misery."

The tiger muttered, "Then I think I am going to eat right now." But the tigress snapped and ordered him, "Stand back! Be still! It is not proper to eat pregnant prey."

The tiger ignored her admonition, and with his tail swooped above his head, he pounced, jaws open, ready to kill.

Satya Pìr called out to the tiger from the womb, "You have just forfeited your dotage! I am Satya Pīr. Anyone I curse is instantly turned to ashes."

As soon as he heard the pir's clarion call, the tiger knew it to be true; he lowered his head in obeisance, and wrapped his tail around his own neck in submission. The tiger and tigress then slunk away, but soon a lion came to see the humans huddled at the foot of the tree. This lord among lions moved forward, ignoring the twenty slithering cobras that had also been attracted and were gnashing their fangs in anticipation.

Satya Pīr called out, "Hey listen, you lord of lions! You may be the king of animals, you may be afraid of no one, and I am sure you can kill a monkey with one swipe of your paw to dine on his flesh. But know now that you are on the sure path of death and destruction. Know without doubt that a single blow from my hand will send you to hell, the abode of Yam!" Registering the menace of those truthful words, the lion king crouched down on the ground with grass between his teeth in surrender. $\mathrm{He}$ then jumped up and ran far away, fortunate to have preserved his life that day.

After the lion had been driven off, some bears loped up in quest of a quick kill. The male and female bears circled the tree until Satya Bhagavān called out, "If you know what is good for you, you bears will leave now, otherwise you will be destined for death in Yam's house!" The bears, too, wasted no time in scampering away.

Till the tenth watch did this continue, as Kṛ̦̣nahari Dās mellifluously sings. ${ }^{11}$

11. Kṛṣṇahari Dās, 27-28. 
It takes the constable seven days to return to the king's court, where he describes the convoluted path they have followed, traveling from one river ghàt to the next, eventually to reach the Kul Forest where he left Sandhyāvatī. The king is pleased to have the business over and done with.

Meanwhile Sandhyāvatī and her two serving girls are wracked with hunger and thirst and, remembering the name of God, cry out for help. The Prophet alerts Âllā, who in turn consults with Bidhātā, the God of Fate, and then summons Jibril to descend in the guise of a watchman who seemingly just happens to stumble across them. Jibril provides them with food and water and swiftly returns to heaven.

From inside Sandhyāvatī’s womb, Satya Pīr meditates on Lokmān Hākim, who in an instant miraculously materializes. He asks Lokmān to construct an impregnable royal palace with ten doors made of iron, each door lavishly decorated with rubies and precious stones, and each equipped with secure lock and key. The building should rise two full stories above the ground floor, and be replete with fresh drinking water and palm trees. He also instructs him to construct seven private bathing ghāts, and to provide for every want and need of Sandhyāvatī and her servants.

Lokmān Hākim diligently sets about his task, constructing the different buildings, including five- and nine-spired temples. ${ }^{12}$ Celestial gandharvas arrive, and soon the grounds are teeming, seemingly populated by tens of millions. Even Indra with his vidyādharis visits from heavenly Indrapuri. The golden citadel is studded with rubies, pearls, and diamonds. When it is completed, after about a day, Lokmān Hākim takes his leave. A palanquin is sent for Sandhyāvatī and her servants, who are understandably overwhelmed at their opulent turn of fortune. The place is more lavishly appointed than anything ever seen in Bengal, including her father's citadel. And of course there is a masjid, an item not found on her father's palace grounds.

This is the way of Satya Pìr: he gives sons to the childless and riches to the poor, if you but worship him with respect.

Sandhyāvatī's time has finally come, a dark night in the month of Māgh. In agony, she laments her inglorious fate for having innocently sniffed a flower.

She eventually gave birth to a clot of blood. What can be said of the pir's promise? There were no arms, no legs, no head, no ears, no nose, no mouth. Ever so slowly did the clot ooze out, a quivering mass of congealed blood. This was how Satya was born. ${ }^{13}$

12. The pañcaratna, literally "five gems", is a typical construction for a temple in Bengal; it has a slightly arched pavilion with one spire (sikhar) on each corner, and a central elevated pavilion with a single spire $(4+1)$. The navaratna or "nine gems" emerged in the seventeenth century, adding another level with four spires $(4+4+1)$. See David McCutchion, Brick Temples of Bengal: From the Archives of David McCutchion, ed. George Michell (Princeton: Princeton University Press, 1983).

13. Kṛ̣̦nahahi Dās, Baḍa satya pīr o sandhyāvatì kanyār puthi, 32. 
Sandhyāvatī laments the cruel work of fate, the double shame of being pregnant and then not delivering a child. "A woman without a child suffers a fruitless lifepeople will wonder: what kind of tree produces no fruit?"14 She cannot understand, because everything has been so clear in her dreams that she would bear a son who would be a jewel among men. To be banished because of her pregnancy, which has turned out to be a strange event producing no child at all, angers and confuses her, fueling her grief.

After rehearsing in extenso her mind-numbing tragedy, Sandhyāvatī gathers her wits, takes her servant girls, and with resolve carries the clot of blood to the banks of the Begavatī River. Filled with sorrow and remorse, she hurls the mass into its swirling waters. As it begins to sink, a large female turtle rises from the depths and swallows the clot. ${ }^{15}$ Sandhyāvatì bathes and heads back to her forest dwelling. The turtle swallows hard, and soon the clot is encased in a leathery egg, with Satya Pīr inside the egg inside her womb. Then Satya Pīr works some more of his magic, and after being ensconced in her belly for only ten watches (about four hours), he is hatched in the shallows, fully formed. He quickly scrambles across a shoal and onto a sandbank. As he looks on, the turtle is transfigured-she becomes a splendid heavenly nymph, a vidyādharī. Previously she was a brāhman widow, who, for the offense of eating raw meat, was transmogrified into a turtle, scavenging food on the banks and deep below the surface of the waters. But she also received a boon to ameliorate that offense: she was promised that she would hold none other than the Lord Nārāyan in her womb, albeit for only a span of ten watches. With that promised act, she will be exonerated and dispatched to Vaikuntha heavenand Satya Pīr has made it so. ${ }^{16}$

14. Kṛșṇahari Dās, 33 .

15. Turtle is kacchabinī, a generic term which in this context points to sweet water riverine and estuary-dwelling turtles, which grow sufficiently large to swallow a mass the size of a newborn. At the time of the text's composition, it most likely referred to one of the six species of Batagur, all of which are nearing extinction today.

16. The turtle's role in serving as the vehicle for Satya Pir's birth in the water invokes the image of the cosmogonic sequence of Dharma Thākur as Nirañjan creating the universe out of the void (śūnyatā), with the turtle emerging from the primal waters. See Rāmāi Paṇụit, Śūnyapurāṇ, ed. Cārucandra Bandyopādhyāy, with an introduction by Muhammād Śahīdullāh and Basantakumār Caț̣̣opādhyāy (Kalikātā: Satīścandra Mukhopādhyāy from Basumatī Sāhitya Mandir, n.d. [preface dtd. 1336 Bs (ca. 1929)]), Șrṣti pattan, section 3, vv. 70-103, pp. 18-24. A more recent edition transcribes the text identically; see Rāmāi Pạ̣dit, Śūnyapurān (śūnyapurāṇ, saṃjāt paddhati, dharmapurān), ed. Bhaktimādhav Caț̣̣opādhyāy (Kalikātā: Phārmā Ke El Em Prāibheṭ Limiṭeḍ, 1977), Ṣrṣti pattan, sec. 3, vv. 70-103, pp. 74-76. For more on the association of the turtle with Dharma, see Āśutoṣ Bhațāaārya, Bāṃlā mañgalkābyer itihās, 6th ed. (Kalikātā: E. Mukhārjī āyāṇḍ Koṃ Prāibheṭ Limiṭeḍ, 1381 Bs [1975]), 621-26. For a history of the speculation regarding the tortoise among worshipers of Dharma, see Frank J. Korom, “"Editing’ Dharmaraj: Academic Genealogies of a Bengali Folk Deity," Western Folklore, 56, no. 1 (1997): 51-77. 
As soon as the turtle is released to heaven, Satya Pīr encounters Khoyāj Jendā Pīr [Khijr], who dwells in those waters. Satya Pīr persuades him to accept him as his student (murid). As his teacher (mursed), Khoyāj coaches him for five years, after which Satya Pīr is ready to begin his new life's work. ${ }^{17}$

\subsection{THE MARVELOUS TALES OF SÜPHİ SAINTS}

So begin the miraculous adventures of Satya Pìr, on his mission to meet the spiritual and worldly needs of those who petition and honor him, regardless of their religious orientation. He first goes to the courts of Mālañcā, and afterwards uses his wonder-working power to convince everyone from kings and cobblers to prostitutes and merchants that they share in a common humanity which prospers when the divine is properly acknowledged and suffers when the divine is denigrated. He preaches from the Korān and the Bhāgavata purāna, lecturing imāms and brāhmaṇs equally. His immaculate conception, effected through a flower sent to earth by God, signals that he lives a deservedly charmed life. Âllā promises that nothing can kill him, so he survives every peril, even when strapped to the mouth of a cannon, which is fired to no avail. The beginning of the story cues an expectation in the audience that eagerly enters Satya Pīr's fantastic world; it declares a dramatic mode familiar to nearly every inhabitant of the Bangla-speaking regions of the South Asian subcontinent (the region today comprised of the Indian states of West Bengal, northern Orissa, and parts of Assam, and the nation-state of Bangladesh). The sensational exploits of holy men and women of various religious persuasions, their interactions with gods and goddesses, jinns and angels, and a host of other celestial figures are woven into a common romantic thread. Though they circulate in a variety of slightly different but closely related literary and performative genres, these tales can be indexed generically as kathā, simply story, tale, narrative, or fiction, a vernacular storytelling form that has its roots in ancient Sanskrit literary traditions as much as in Persian and Arabic and related languages such as Avadhī, Hindavī, and what in colonial times was called Hindustāni, but now more recently in Urdu. ${ }^{18}$ Like traditional heroic romances everywhere, they inhabit a world where the unthinkable is commonplace. They speak to surviving in the all-too-often hostile climate of Bengal, the vagaries of encountering jungly beasts and serpents, endemic disease, and the predations of unscrupulous rulers and their ever-present

17. Kṛṣnahahari Dās, Baḍa satya pīr o sandhyāvatī kanyār puthi, 33-36.

18. The pìr kathās, or stories of the sūphì saints, find expression in a variety of genres in addition to

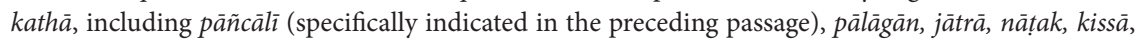
$k \bar{a} h i n \bar{i}$, and so forth; their forms and functions will be described as needed. Significantly, all of these forms are vernacular and half of them unique to Bengal, but one should resist automatically equating the forms directly to their analogues and homonyms in other North Indian languages, because the form and semantic field so designated may not always be identical. 
merchants. But apart from the names, is there anything distinctly Islamic or even religious about this entertaining vignette of Satya Pīr's birth?

The author invokes Āllā and Mohāmmad, and the angel Jibril, which clearly frames the narrative in nominally Islamic terms. But Âllā is also called by the additional name Bhagavān Satya Narāyān in a terminology that then and today would be instantly recognized as an epithet of the Hindu god Kṛṣna. So too the appellation Nirañjan, the Stainless One; commonly used to invoke Viṣnu-Kṛ̣ṇa or Nārāyaṇ, it also equally serves as one of the most common appellations of Âllā in Bangla literature-a shared descriptor that would seem to capture commonly held notions of highest divinity as formless and pure. In the first lines following the various encomia and supplications, the homey colloquy in heaven (bhest) where Mohāmmad queries Āllā just as a minister might his king, jars the traditional images of Âllās omniscience, his ninety-nine immaculate qualities, and his generally accepted formlessness. The exchange mimics a king's court. Immediately after their consultation, God summons Jibril and then dispatches him on his errands. That court is of course heaven, or bhest, but heaven is also called in this text by the common vaiṣnav designation vaikuntha. The actions of the characters in that special place likewise seem to challenge most Islamic descriptions of heaven, even veering away from what the author himself, Kṛṣnahari Dās, shifting into a mildly homiletic mode, outlines in his comparison of heaven and hell. What about the traffic of celestial figures in and out of this courtly heaven? Is fetching a houri or peri (hurpāri as færie) a menial task one associates with an angel Jibril, presumably the archangel of the name who, according to the mainstream tradition, significantly shared the Arabic Qur'ān with Muhammad? Is the invocation of Prophet (nabī) and Apostle (rachul/racchul) sufficient to call the tale Islamic when Kṛ̣na and Rām are likewise invoked? Is it within Mohāmmad's character, as we know it from the traditional Arabic sirā and hadith texts, to devise a scheme wherein an exemplary, quality-laden færie would be tricked into committing such a minor, and certainly ambiguous, offense to warrant a thirty-six-year exile on earth? Where in the Islamic tradition do we hear of any character who, having gained heaven, returns to earth, save Mohāmmad's mi ${ }^{\mathrm{r}} \mathrm{r} \bar{j}$, which is explicitly invoked when the turtle that has borne Satya Pīr ascends to heaven? Indeed, as the author says, only God knows the mysteries of such action! How often do we hear of any heavenly figure, much less a færie, arguing with Jibril or with Mohāmmad about a divine decree? The argument Cāndbibī puts forward centers on the concept of the traditional Indic concept of karma, its consequences for rebirth, and who might expect to suffer negatively. What does Fate, especially delivered by the god Bidhātā, have to do with it? Who knew that at least forty other times God had sent down færies to give birth to special pirs to do his bidding? And among those forty prior descents, was it normal for Āllā to send a færie into the womb of a brāhman queen, and not just as a færie, but as a jabanā or musalmāni woman? Impregnation from sniffing a flower is not an unknown trope in popular Bangla tales, but crediting Âllā with the 
instigation seems to put a new twist on it. ${ }^{19}$ Can Sandhyāvatī’s condition be considered an immaculate conception, or should we consider the nose just another orifice that leads to the womb, reminiscent of the varied ways in which the mythology of the purānik gods and goddesses of India fantastically procreate? Either way we must ask who, then, is the father. What does Âllā mean when he says he himself will come down as Satya Nārāyaṇ for his hinduyāni audience and as Satya Pīr for his musalmāni followers? Yet he has Satya Pìr fetched to make the descent in his place, but only with Satya Pìr's consent. Once in the womb, this special pir speaks, commanding wild animals to proceed at their peril, which sends them packing, a variation of the widely accepted belief that pirs and warrior gājis talk to and control animals in the wild, the preferred home of these mendicants. But Satya Pìr also summons Lokmān Hākim, who executes his bidding without question. Are we supposed to understand that Lokmān Hākim is the same Luqmān of the Arabic Qurān, surā 31? How can Lokmān magically appear when called by Satya Pīr to construct a palace deep in the heart of a dense jungle in south central Bengal, and then do it in one day?

The text leaves us with many awkward questions unanswered if we attempt to resolve the actions of its characters with what we know of traditional Islamic history, or attempt to rectify the nature of divinity as described. To force the narrative into the genre classification that aligns with traditionally accepted Islamic religious discourses of history, theology, and law will inevitably do more violence than Procrustes himself could have engineered. These stories fall outside the traditional strictures of history, theology, and law, and therein lies their secret power and a key to their interpretation. Though the bulk of the narratives' propagation and circulation is the result of the performances of storytellers and performing troupes, oral literature, with its widely recognized modes of reproduction, maintains the fidelity of the tale. But the tales are not without their physical props and different modes of visual circulation, in both manuscript form and painted image.

Those who worship according to the prescribed ritual form of sevā or $p \bar{u} j \bar{a}$ often sing the tales in the presence of images representing the various pirs, devs, and devis who control the powers of protection. But the exploits of these musalmani luminaries and hinduyani heroes and deities are at the same time extolled by singers of tales apart from formal worship. ${ }^{20}$ Their narratives are illustrated in

19. One popular story (with multiple variants) tells of a king who has no sons, but one stunningly beautiful daughter who plucks a flower from the river and after smelling its fragrance finds herself pregnant; she escapes her father's wrath by fleeing to the forest where she meets a trader, who steals her away, but abandons her son, who is raised by a tigress. The boy eventually recovers his rightful kingdom as inheritance. See eight variants of the story in Ālamgīr Jalīl and Sāmīyul Islām, eds., "Āṭkuḍe rājār pālāgān o kissā saṃkalan," in the Bangla Academy journal Lok sāhitya 15 (Pauṣ 1385 [January 1979): 1-197. A variation of this trope will appear again in the story of Badar Pīr, in chapter 2.

20. It should be noted that there are several forms of textual performance that blur the distinction between chanting and singing. Mary Frances Dunham's analysis of jārigān highlights the performance 
painted pictures called patacitra or pațs, with sequential frames that function much like contemporary cinema storyboards. The visual narratives are produced by a hereditary groups of artisans-pațūs, pațidārs, or citrakārs in different parts of Bengal-who paint their tales frame by frame, originally on cloth, but much more likely now on paper. There is textual evidence of this practice of illustration dating back more than two millennia in South Asia, but no example exists today that is older than the mid-fifteenth century. ${ }^{21}$ The pat illustrations are surprisingly mobile, and it is impossible to tell where certain themes and even painting techniques originated. Today the tales illustrated by these paintings-and the numbers of individuals practicing this art have diminished considerably-constitute much of the repertory of itinerant performers and troupes of actors who stage the dramas in open-air jātrāa, pāñ $\bar{a} l \bar{l}$, and pālagān performances. ${ }^{22}$ Historically, the pats were deployed in those public performances to provide visual context for the actions being described and often enacted; fewer and fewer performances today

of semi-epic ballads, focusing primarily on the Shi'i martyrs of the Karbala narrative, and David M. Kane's analysis of the sylheti nāgri "melodic reading," called puthi porāa, demonstrates the way texts form the classical romance and sūphì repertoires of musalmāni literature; see Dunham, Jarigan: Muslim Epic Songs of Bangladesh (Dhaka: The University Press Limited, 1997), and Kane, Puthi Porā: "Melodic Reading" and Its Use in the Islamisation of Bengal (London: Sylheti Translation and Research, 2017). For a related analysis of the preaching style of contemporary Bangladeshi imāms, including analyses of the tonal and melodic patterns adopted while code-switching during the public recitation of different texts and expository styles, see Max Stille, "Poetics of Popular Preaching: Waz Mahfils in Contemporary Bangladesh" (PhD diss., Universität Heidelberg, 2016).

21. Today the pats are of two basic types: lotāipat, or scrolls (both vertical and horizontal registers), and caukāpat, which are quadrangular in shape (squares or rectangles, usually with a central figure and surrounding registers). For a concise yet technically precise description and taxonomy of the styles of paintings in popular art, not only of the pats but of clay plates and pots in the same vein, see Nisir Hossain, "Folk Painting," in Arts and Crafts, ed. Lala Rukh Selim, Cultural Survey of Bangladesh Series 8 (Dhaka: Asiatic Society of Bangladesh, 2007), 499-510. With the kind permission of the British Museum, the cover and frontispiece of the current volume are taken from one of the oldest extant Bengali pats, c. 1780, as described by T. Richard Blurton, Bengali Myths (London: The British Museum Press, 2006), 67-72. The scroll itself is more than 42 feet long and contains 54 distinct registers, but is incomplete on both ends. Part of the scroll illustrates the stories of Satya Pīr, Mānik Pīr, the central portion that of Gāji Pīr, with several other as-of-yet unidentified tales. The image adorning the cover and the frontispiece of the current book are from this pat. For illustrations and contemporary ethnography of the tradition in West Bengal, see Frank J. Korom, Village of Painters: Narrative Scrolls from West Bengal, with photographs by Paul Smutko (Sante Fe: Museum of New Mexico Press, 2006), and more recently, Amitabh Sengupta, Scroll Paintings in Bengal: Art in the Village, foreword by Kapila Vatsyayan (Bloomington, IN: AuthorHouse, 2012). For the way the tradition has survived into the present, see David McCutchion and Suhṛdkumār Bhaumik, Patuas and Patua Art in Bengal (Calcutta: Firma KLM, 1999).

22. See the comprehensive ethnographies of indigenous theatre by Syed Jamil Ahmed, Acinpakhi Infinity: Indigenous Theatre of Bangladesh (Dhaka: The University Press Limited, 200o) and In Praise of Nirañjan: Islam, Theatre and Bangladesh (Dhaka: Pathak Samabesh, Losauk, 2001). See also the recent ethnography by Saymon Zakaria titled Pronomohi Bongomata: Indigenous Cultural Forms of Bangladesh, with a foreword by Tony K. Stewart (Dhaka: Nymphea Publications, 2011). 
are illustrated in this way, though the technique stubbornly survives. The mobility of the paintings goes hand in hand with the itinerant troupe performances in such a way that laces together the disparate rural regions of the Bengali-speaking world into a common or shared cultural experience, the ongoing experience and physical instantiation of the shared cosmologies of the tales.

This convergence is further solidified by the written word, though not usually in the high literary mode of early Bangla belles lettres-another reason for the texts' easy dismissal-though there can be little doubt that many of the authors were acutely aware of and educated in those genres, especially when authors such as Bhāratcandra, Rāmeśvar, Kṛ̣̣narām Dās, and Oyājed Alī also composed numerous literary texts. Many of the stories that constitute the central corpus of these performing troupes, the very tales illustrated by the pațuass, date as far back as the late fifteenth century, though most extant today are the product of successive centuries. There are hundreds upon hundreds of such manuscripts housed in contemporary repositories in Dhaka University, the Bangla Academy, the Asiatic Society of Bangladesh, Calcutta University, the Bangīya Sāhitya Parișat, Viśva Bhārati in Santiniketan, and a host of other regional repositories in places such as Rangpur, Kumilla, and Chittagong. The stories in these manuscripts became the initial source for large numbers of inexpensive printed texts after the advent of the printing press in India in the early decades of the nineteenth century. By the mid- to late nineteenth century the stories of the gods and goddesses and pirs and bibīs flourished in print, mass-produced by small presses, such as Íśāncandra Sîl, Viśvambhar Lāhā, and Akșaykumār Rāy, while presses such as Siddikiyā Library, Gaosiyā Library, and Habibī Press in Calcutta, and Śulābh Jantra in Dhaka specialized in titles that would appeal to a largely musalmāni audience. Some new fictional tales in the romance genre, but only incidentally involving pirs and other such figures, were composed as the corpus grew, some clearly for entertainment (in size and function roughly equivalent to the European novella), while others were more overtly didactic. Technically the didactic literature is rightly called nasihat $n \bar{a} m \bar{a}$, or "literatures of instruction," but the popular fictional romances that were generated in the same physical print form have also been folded into the genre, often as the antithesis of the former. ${ }^{23}$ This blurring of genres is a sure indicator of the lackluster acknowledgement of the literature's worth by the colonial administrators who collected these titles for the National Library, Calcutta University, the Asiatic Society in Calcutta, and the India Office Library and the British Library's Oriental Collections in London-those collections yielding the bulk of extant

23. For discussion of the genre of nasihat nāmā as instructional literature, see Rafiuddin Ahmed, The Bengal Muslims, 1871-1906: A Quest for Identity (New York: Oxford University Press, 1981), 82-101; and Sufia M. Uddin, Constructing Bangladesh: Religion, Ethnicity, and Language in an Islamic Nation (Chapel Hill: University of North Carolina Press, 2006), 67-71. 
titles today (and they represent only a fraction of what was published). ${ }^{24}$ The $p \bar{i} r$ $k a t h \bar{a}$, however, retained their distinct identity and remained true to the formulae of romance over the centuries.

It was the older stories, however, that endured, becoming "classics" by their popular repetition in performance and in print; that is, they are the tales that speak to generation after generation because the texts remain relevant and the stories sufficiently malleable to be revalorized, continuing to be meaningful, without having to introduce new features or change plots. ${ }^{25}$ As testament to their durability, a substantial number of those tales of the pirs are still reproduced in inexpensive chapbooks today, though somewhat less widely circulated than a century ago. ${ }^{26}$ The classic tales of Baḍa Khān Gājī, Dakșiṇ Rāy, Mānik Pīr, and Satya Pìr, among others, were printed and reprinted repeatedly for the better part of a century starting around the 1850 s and, in this flurry of activity, set the stage for the emergence of new female heroines, such as Bonbibī and Olābibī. The greatest output in print peaked in the last decades of the nineteenth century and spilled over into the first two decades of the twentieth, a production level that curiously seems to have been in direct proportion to the amount of pressure brought to bear by the Salafists, Faraizis, and other Islamist reformers dedicated to eradicating their presence-certainly a circumstantial and statistical correlation worth noting, for it suggests these texts meant something to their audiences they were loath to relinquish. While this literary efflorescence peaked nearly a century ago, it still refuses to succumb to censorship, though the tools of suppression and the money available for it are far greater today. The narratives are numerous and widespread and, when compared to the mythology of their hinduyāni counterparts, are no less entertaining in their dynamic and often unpredictable twists of plot. The confluence of visual representation, public performance, and print circulation expresses a world that is distinctly Bengali, but also shares much with other vernaculars in the colonial setting. ${ }^{27}$

24. For the documentation by the India Office Library of this prodigious literature in the mid- to late nineteenth century, see Tapti Roy, "Disciplining the Printed Text: Colonial and National Surveillance of Bengali Literature," in Texts of Power: Emerging Disciplines in Colonial Bengal, ed. Partha Chatterjee (Calcutta: Samya, 1995), 30-62.

25. My understanding of the classic is very much conditioned by Frank Kermode's provocative essay; see Kermode, The Classic: Literary Images of Permanence and Change, The T. S. Eliot Memorial Lectures 1973 (Cambridge, MA: Harvard University Press, 1975).

26. For an introduction to these numerous productions, see Qazi Abdul Mannan, The Emergence and Development of Dobhasi Literature in Bengal (up to 1855 AD), 2nd ed. (Dacca: Bangla Academy, 1974).

27. For a very nuanced reading of the ways in which educated Bengali Muslims fashioned identity through interaction with indigenous literary and cultural traditions, the analogue to the development of bhadralok culture, see Neilesh Bose, Recasting the Region: Language, Culture, and Islam in Colonial Bengal (Delhi: Oxford University Press, 2014). For other perspectives on the creation of Muslim identities, see again Ahmed, Bengal Muslims, and Uddin, Constructing Bangladesh. In a recent 
Like their Hindu complements, which extol the material virtues of worshiping the goddess Candīi or celebrate the great feats of the nāth jogì Gopicand, the tales of the pirs and bibis demonstrate the practical advantages of paying court to these holy figures: they are credited with increasing one's wealth, extending protection from disease, healing livestock, encouraging the resourcefulness of women to keep the world in order, and providing a counter to the many dangers of the jungle. For instance, Olābibi protects her followers from cholera and other water-borne diseases endemic to the swamps and waterways. A simple offering of rice powder mixed with banana, milk, cardamom, and sugar, called sirnī or śinni, will satisfy Satya Pīr sufficiently that he will stave off penury, as our author promises in the opening to the tale quoted above. Indeed, if one is sincere and diligent in sharing with others the pir's efficacy, Satya Pìr can help one to amass great wealth. These popular figures mediate the vicissitudes of the world with a goodness and grace that invites, if not subtly induces, their listeners to strive for a better existence through their example. On the surface, the primary characters seem to be functionally equivalent to the various hinduyāni gods and goddesses and the ever-present nāth jogì, sannyāsī, or vaiṣnav ascetic vairāgī. It is with these figures that they often interact through a kind of "exchange equivalence," which we will explore further. ${ }^{28}$ Debabrata Naskar has mapped most clearly the sets of parallel figures that come into play in the southern reaches of the Bangla-speaking world, where most of these stories circulate. ${ }^{29}$ In four chapters, he examines in turn: the song performances of the goddesses, the devīpālā (Şitalā, Manasā, Șașthī, Lakșmī, Caṇ̣ịi, Biśāāākṣī, Nārāyaṇī, Durgā, and Santoṣi Mā); the tales of the gods, devpālā (Dakṣin Rāy, Pañcānanda, Benākī, Cāṣīmahādev, Basanta Rāy, Śani, and Dharma Țhākur); stories of the matrons, bibipālā (Bonbibi, Olābibi, Āsānbibi, Sātbibi, Naybibi, Āorajbibi, Darbārbibi); and the tales of the sūphì masters, pìr o gājī pālā (Mānik Pīr, Baḍa Pīr Sāheb, Satya Pīr, Mādār Pīr, Pīr Gorācã̃d, Mobārak Gājīi, Baḍa Khã̃ Gājī, Deoyān Gājī, Raktān Gājì, and Hajrat Jāber). These are the figures that populate the religious imagination of the Sunderbans. They are under-

dissertation, Epsita Halder has explored the ways the Karbala narrative was instrumental in defining musalmāni group identities and the ways the debates reverberated through the popular press, especially musalmāni periodical literatures; see Halder, "Of Blood and Tears: Tracing Self and Community in Karbala Narratives of Bengal (Late 19th to Early 2oth Century)" (PhD diss., Jadavpur University, 2017), esp. chaps. 4, 5, and 6.

28. The concept of "exchange equivalence" can be found initially in Tony K. Stewart, "In Search of Equivalence: Conceiving Muslim-Hindu Encounter through Translation Theory," History of Religions 40, no. 3 (Winter 2001): 261-88. This essay has been twice anthologized, first in India's Islamic Traditions: $711-1750$ (with a faulty title), ed.. Richard M. Eaton (Delhi: Oxford University Press, 2003), 363-92; and again in On Figuring Religions: Comparing Ideas, Images, and Activities, ed. Subha Pathak (Albany: State University of New York Press, 2013), 229-62.

29. Debabrata Naskar, Cabbiś pargaṇār laukik devdevĩ: Pālāgān o loksaṃskṛti jijñāāā (Kalakātā: De’j Pābiliśiṃ, 1406 Bs [1999]). 
stood to interact with one another, and people turn to them whenever they are in need of something that falls within the domain of their personal powers, regardless of overt religious persuasion. The distinctions of formal religion matter not at all; these figures help anyone to navigate the vagaries of basic survival.

With the way religion was politicized and conflated with ethnic and linguistic identities in the nineteenth century, ultimately culminating in the separation of India from Pakistan in 1947 (and which for different reasons led to the division of East Pakistan from West Pakistan to create Bangladesh in 1971), it is easy to see why today the perception of a functional equivalence of recognized Muslim holy figures with Hindu analogues would lead some to try to suppress the tales of popular pìrs and pìrānīs, phakìrs, gājīs, dārveśes, and bibìs. Consistent with fundamentalist impulses in theistic traditions around the world, starting in the mid- to late nineteenth century, reform-minded Muslims attempted to expunge anything deemed a local accretion, though these so-called "local" traditions have long roots in the Bangla-speaking world, in many instances stretching back to the fourteenth and fifteenth centuries, perhaps further (manuscripts simply do not survive in that climate, with the ravages of mold and mildew, white ants, and floods, so documentation is necessarily limited). The easy accommodation of yogic meditation and magic by sūphi practitioners, the similarity of devotional expression between the vaiṣnav chanting the names of Kṛnna in kirtan or jap and the recitation of the qualities of Âllā in sūphì jikir (from the Persian zikir), and the gradual adoption of the Bangla language as a medium for Islamic discourse-these and many more parallel activities insinuated Islam into the culture of Bangla-speaking peoples over the last seven centuries, ${ }^{30}$ to the point where no matter how zealous the effort, what is local can no longer be extracted without destroying what had grown into a very Bengali Islam. Yet in the nineteenth and twentieth centuries that kind of reform is precisely what was attempted, and that effort received reinforcement from unexpected sources.

With the emergence of the printing press in the colonial environment of the nineteenth century, the tales of the legendary pirs, such as Satya Pìr and other popular figures, found vigorous competition in the form of inexpensive religious tracts prompted by the growing movements championing reform, many of which decried the general failures of musalmāni practitioners to be proper Muslims in the new sense of that term. The legendary pirs, as well as those who had accepted guidance from a living sūphì teacher or murśid, soon found themselves attacked directly in many of these publications. These popular printed texts represented a new modality of public discourse within the Bangla-speaking community. Especially evident was the growing vitriol of Muslim reformers who published

30. Richard M. Eaton has mapped out many of these instances; see Eaton, Rise of Islam and the Bengal Frontier, esp. chaps. 3 and 10. See also M. R. Tarafdar, Husain Shahi Bengal, 1494-1438 A.D.: A Socio-Political Study, 2nd ed. (Dhaka: University of Dhaka, 1999). 
tracts rife with diatribes against the inherent dangers of worshipping pirs and phakirs. Importantly, little distinction was made between pirs who were living and those who were entombed, or, alternately, those whose existence was historically verifiable and those who seemed to function only in the realm of the Bengali imaginaire. Colonial scholars attempting to analyze these popular narratives conflated willy-nilly the historical with the legendary, treating them simply as variations, rather than as the distinct and divergent genres with the different histories they represent.

While foreign and local Orientalist and antiquarian scholars tended on the whole to be dismissive of all stories of this class of religious mendicants, always citing the claims of their miraculous powers and heroic feats as exaggerations aimed to dupe the gullible, the critique from the normative reform-minded factions was much more acerbic and sustained. For instance, one tract writer refers to the misguided worship of "fake" or "fanciful" pìrs (mithya pìr), and explicitly names Satya Pīr and Pāglāi Pīr as leading contenders to misguide the public. ${ }^{31}$ Clearly the reputation of mendicant pirs was in question, judging from the frequent charges of misconduct and hypocrisy, ${ }^{32}$ but the critique of charlatan religious functionaries was not limited to Muslims. For instance, the great vaiṣnav and district magistrate, Bhaktivinode Thakur founded the Gaudiya Math in the late decades of the nineteenth century precisely to make respectable the offices of vaiṣnav vairāgīs, or mendicants, who had so sullied the title vairāgi in the eyes of the up-and-coming bourgeois communities who sought to modernize Bengali society. ${ }^{33}$ Members of the Brahmo Samaj, the Hindu nationalist Arya Samaj, and the Ramakrishna Mission all took stands against religious frauds and poseurs. ${ }^{34}$ Reform seemed to be on everyone's mind, but of course few could agree on what should constitute that reform.

Where there was antipathy towards pirs during this period, it was far greater among the conservative factions of the Islamic community's self-proclaimed purifiers than among Hindus, especially vaiṣnavs, who often saw the tales of the pirrs

31. Sāiyad Śāh Mohāmmad Āli, Mithya-pīr (Kochagrām, Dinajpur: by the author; printed in Kalikātā by Mohāmmad Reyājuddin Āhmād at Reyāul-Islām Press, 1325 BS [ca. 1918]).

32. Phajlar Rahmān, Bhaṇda phakīr (Kalikātā: by the author at Niu Sarasvatī Pres, 1321 Bs [ca. 1914]).

33. For Bhaktivinode's role in reforming the vaiṣnavs of Bengal and the founding of the conservative Gaudịya Mațh, see Jason D. Fuller, "Religion, Class, and Power: Bhaktivinode Thakur and the Transformation of Religious Authority among the Gaudiya Vaisnavas in Nineteenth-Century Bengal" (PhD diss., University of Pennsylvania, 2005). For a more traditional biographical reading in the subgenre of "life and times," see Brian D. Marvin, "The Life and Thought of Kedarnath Dutta Bhaktivinode: A Hindu Encounter with Modernity" (PhD diss., University of Toronto, 1996). For the ways the bhadralok communities seized on this sanitizing movement, see Varuni Bhatia, Unforgetting Chaitanya: Vaishnavism and Cultures of Devotion in Colonial Bengal (New York: Oxford University Press, 2017).

34. The references here are legion, too numerous to mention. 
as a site of communal sharing. The pirs served as a point of equivalence, both to Hindu deities and to various types of mendicants, in form and in function. As we have already suggested, reformers would see the pir kath $\bar{a}$ as truly heretical, not Islamic at all, and some castigated the popular worship at the tombs of pirs. One author named Garīb delivered a particularly scornful critique of the powerlessness of the dead $p \bar{i} r$ by arguing that if the pir could not even keep the flies from swarming around the food offerings made at his tomb, how much help could he possibly be to the supplicant? ${ }^{35}$ This technique of excoriation and mockery, which hinged on emotional sophistry, was not uncommon. Another popular tack that pushed the charlatan profile was to alert the unwary about ostensible religious teachers who were little more than thieves and scam artists, addicted to luxurious living, indulging their taste in elegant foods, milking the unwary of their hard-earned rupees. ${ }^{36}$ Another author went considerably farther in his indictment by stereotyping pirs and phakìrs as drug-addicted home-wreckers in this degraded Kali Age. ${ }^{37}$ Using the shorthand label of the märphati path, others took a more theological course by attacking as errant the sūphi practices that were designed to elevate the individual to a higher realm of consciousness, calling those practices a guaranteed way to perdition. ${ }^{38}$ As Munsi Nachiraddin Chāheb and Adhin Mahāmmad Hādek Orephe argued in Jālālātal phokrā, it was because mārphati practices depended on the guidance of a human teacher, usually a pir or phakìr serving as murśid, that any sober-minded practitioner would see the sūphī path as anathema to śariyat. In that Islamist ritual economy, śariyat, it was argued, was founded solely on God's guidance and was the only reliable recourse, whereas the fallible teachings of a mere human (mis)guided the devotee in the märphati tradition. This jointly authored book especially condemned the mendicants' love of food and food offerings, and included an exceptionally pointed diatribe directed at the evil practice of tomb worship as the pathway to Saytān (replete with a drawing on page 13 graphically illustrating the results). Saytān, they allege, is said to corrupt the minds of the phakirs by speaking to them through their meditation, so the belief in the sanctity

35. For this scathing critique of the alleged stupidity of tomb worship, see Garìb, Iblich nāmār puthi (Kalikātā: Śrī Akṣayakumār Rāy eṇ̣̣ Kompāni, 1287 Bs [1879-80 CE]), esp. the introductory pages, 2-4. Āhmad Śariph and Anisujjamān both consider the author of this Iblichnāmā to be Munśi Garībullāh, not Phakīr Garībullāh, who was the author of Iusuph jolekhā, Jainganāmā, Sonābhān, Satyapìrer puthi, and Āmir hāmjā, as cited in Garībullāh, Sāh garībullāh o janganāmā, ed. Muhammad Abdul Jalil (Ḍhākā: Bāṃlā Ekāạemī, 1991), 22-23.

36. For a vigorous warning against the corruption of bogus phakirs and pirs in this final cosmic age of degradation, see Ābbās Āli Nājir, Kalir phakìrer khelā (Lakpur: by the author, 1920); for a condemnation of the bauuls and other fakirs as immoral and guilty of not practicing a legitimate or proper Islam, see Reyājuddin Āhmād, Bāul dhvañsa fatwa (Calcutta: Mohammadi Press, 1925).

37. Mahāmmad Āinaddin Sāheb, Nachihate āhale kali (Kalikātā: Phasih Uddin Ahāmmad, Mahāmmadī Lāibrerī, 1337 Bs [ca. 1930]).

38. Munśi Mohāmmad Hāphej Ālī Deoyān, Gupta māraphat bā nadhihate pherāun (Kalikātā: Gaosiyā Lāibrerī, Nūruddīn Āhammad, n.d.). 
of the pir not only was grounded in the hubris of human ignorance, but was truly diabolical. ${ }^{39}$ If it was so among the pirs one encountered in person, how much more serious and damning the critique against the imaginal figures such as Mānik Pìr, Bonbibì, and others in the set of tales we are examining.

Subsequently, these conservative factions found their arguments paradoxically, albeit indirectly, supported by the authors responsible for writing the new histories of Bangla literature. These projects of establishing a nationalist secular literature, no doubt inspired by Dīneścandra Sen's Banggabhāṣā o sāhitya ${ }^{40}$ and his subsequent History of Bengali Literature and Language, ${ }^{41}$ reached their zenith in the first half of the twentieth century. The efforts expanded to multi-volume surveys like those authored by Sukumār Sen, whose text covered nearly three thousand printed pages, ${ }^{42}$ and Asit Kumār Bāndhyopādhyāy, whose monograph was only slightly shorter, ${ }^{43}$ to name two of the most influential among the many of that generation. The recovery of vernacular literatures, spurred by the nation-building projects associated with the emerging institutions of higher education and the literary academies for the preservation of manuscripts, and so forth, were overtly secular in conception, but in Bengal, heavily influenced by elite Hindu bhadralok ideals in their execution. ${ }^{44}$ In these massive and highly influential projects, the tales of the pirs were treated as little more than sources of rural amusement and diversion. "Derivative" was the dismissive characterization of nearly all musalmāni literary productivity, largely, I think, because the most sophisticated literary texts were Bangla versions of the heavily allegorical sūphì romances or premākhyān, a high literary form derived from Avadhì and Hindavī productions (prem kahānī) that hark back to the Persian masnavī story literatures. Sukumār Sen refused to include

39. Munsi Nachiraddin Chāheb and Adhin Mahāmmad Hādek Orephe, Jālālātal phokrā (Kalikātā: Āli Hāniphi, printed by Mūnsi Golām Māolā Chāheber Moratajabi Pres, n.d. [ca. 1878]). The date on the title page says 1847 BS, which is an obvious misprint (since that would indicate ca. 2440); the date of $1878 \mathrm{CE}$ is provided by the Blumhardt catalogue, which often records the date of acquisition rather than the date of publication, so we can surmise publication would have probably been sometime in the mid- to late 1870s; see James Fuller Blumhardt, comp., Catalogue of the Library of the India Office, Vol. II, Part IV-Bengali, Oriya, and Assamese Books (London: Eyre and Spottiswoode, 1905). The reference to meditation as the entry point for Saytān begins on p. 41 of the text.

40. Dīneścandra Sen, Bañgabhāṣā o sāhitya, ed. Asit Kumār Bandyopādhyāy, 2 vols. (1896; repr., Kalakātā: Paścimbaṅga Rājya Pustak Parșad, 1986).

41. Dinesh Chandra Sen, History of Bengali Language and Literature, rev. ed. (Calcutta: Calcutta University Press, 1954).

42. Sukumār Sen, Bāñglā sāhityer itihās, 7 bks. in 5 vols. (1347-65 BS; repr., Kalikātā: Eastern Publishers, 1383-88 вs [ca. 1976-1981]).

43. Asit Kumār Bāndyopādhyāy, Bāinglā sāhityer itibṛtta, 4 Vols. [1365-80 Bs [ca. 1958-63]; repr., Kalikātā: Modern Book Agency, 1373-90 Bs [ca. 1966-1983]).

44. What has customarily been called the Bengal Renaissance might more rightly be styled the Bengal Hindu Renaissance, for Islam and Muslims were decidedly absent from the academic record of it. 
his survey of the Bangla premākhyān in his multi-volume history of Bangla literature, preferring to keep their study separate in a small format one-hundred-fiftypage monograph titled Islāmi bānglā sāhitya, because in his estimation they were poor translations or unimaginative retellings, little more than clichéd copies of their refined forebears. ${ }^{45}$ But stories of Satya Pìr and the other pìrs and bibìs who populate these tales are several times removed from those allegorical premākhyān in their literary quality, and distinctly spotty or even devoid of the allegorical dimension, which no doubt had the effect of marginalizing them even further since the formal allegory was considered to be a higher form of art. ${ }^{46}$

We might not unreasonably further observe that these early scholars constructing the first Bangla literary histories inherited an academic environment conditioned by colonial antiquarian and Orientalist scholars, foreign and local alike, who saw in such tales little more than syncretistic confusions of religion-Islam in unholy alliance with Hinduism - which rendered them both improper and illicit. Linguists, including the venerable polymath Suniti Kumār Caț̣opādhyāy (in English, Chatterjee), saw the language as a mirror of religious incertitude. He considered the language of these texts to be confused, bastardized, and not proper Bangla at all, because it combined Persian (read: alien) elements with a

45. Sukumār Sen, Islāmi Bāinglā sāhitya (Kalakātā: Ānanda Pābliśars Prāibheṭ Limiṭeḍ, 1400 BS [ca. 1993]).

46. Aditya Behl's study of the major texts of the Hindavi corpus, which flow out of the Persian tradition starting with 'Aț̣ār's Conference of the Birds, confirms just how fundamentally different those allegorical tales are from the set of tales in our study; see Behl, Love's Subtle Magic: An Indian Islamic Literary Tradition, 1379-1545, ed. Wendy Doniger (New York: Oxford University Press, 2012). In a study completed five decades ago, Mantajur Rahmān Taraphdār compared the Persian masnavīs, the Âvadhì and Hindavi premākhyāns, and the Bangla retellings of those same four stories found in Behl-Candāyan (Lor Cānd), Mrgā̃vatī, Padmavatī, Madhumālatī-and contra Sen's position in Islāmi bānglā sāhitya, he found that the Bangla versions constituted new, creative retellings of their intertextual predecessors, not uninspired derivatives. In that analysis, it becomes clear that the overall sophistication and allegorical possibilities of those literary works mark them as fundamentally different from the pìr kathās of the current study; see Bāmlā romānțik kāvyer āoyādhì-hindī pațhhūmi (Ḍhākā: Ḍhākā Viśvavidyālay, 1971). Thibaut d'Hubert's recent study of Ālāol's poetics underscores the sophistication of the Bangla romance of Padmāvatī, arguably the most accomplished of poets to re/create these allegorical romances; see d'Hubert, In the Shade of the Golden Palace: Ālāol and Middle Bengali Poetics in Arakan, South Asia Research (New York: Oxford University Press, 2018). Ālāol's use of high-register æsthetic theories from both Indic and Persian traditions contrasts dramatically with the register of the fictional pīr kathās of our study, which in some instances do look toward those æsthetics, but which are much more akin in spirit to the Urdu and Hindi traditions documented by Frances W. Pritchett; see Pritchett, Marvelous Encounters: Folk Romance in Urdu and Hindi (New York: Riverdale Publishing, 1985), and 'Abdullāh Ḥusain Bilgrāmī, The Romance Tradition in Urdu: Adventures from the Dastan of Amir Hamzah, trans. Frances W. Pritchett (New York: Columbia University Press, 1991). For more on the Urdu masnaviss, see Anna Suvorova, Masnavi: A Study of Urdu Romance, translated from the Russian by M. Osama Faruqi (Karachi: Oxford University Press, 2000). 
Sanskrit-derived (read: indigenous) Bangla into what became known as dobhāṣi (double- or two-language speech). ${ }^{47}$

The combined effect of these different pressures was to relegate the tales to the Victorian and Bengali bhadralok elitist (and even more recently, Marxist) curio cabinet of naïve folktales suitable only as entertainment for the masses, stories that came from and still belong in the kitchen. There was among the intelligentsia a palpable ambivalence about folklore and folktales, for they were indigenous, which was good for the emerging notions of nationalist identity, but they were considered naïve and childish, for some an embarrassing part of Bengal's cultural heritage..$^{8}$ The response, whose effects linger today, was to hide these tales from the official record of Bengal's religious and literary production, though after five centuries of circulation they continue to enjoy wide popularity and are performed regularly in dramas and public recitations, as noted above. The most deliberate corrective to the systematic omission of musalmāni bāinglā in literary history was Āhmad Śariph's Bāngālì o bānglā sāhitya, which did not appear until 1983, more than a decade after Bangladesh's independence. ${ }^{49}$ The foundational work that led to Śariph's project was undertaken by Muhammad Śahīdullāh, ${ }^{\circ}$ Ābdul Karīm, ${ }^{51}$ and Enāmul Hak..$^{52}$ These linguists, historians, and scholars of literature and religion realized that, while all manner of new musalmāni literatures could be generated in the high register of Bangla, sādhu bhasșa, it was the older pũthi literature that captured the real emotional core of the Bengali Muslim community (jätiya), the $b h \bar{a} v$ or emotional core of its literary production..$^{53}$ They began the process of rehabilitating these and a host of other early musalmāni literary forms by establishing

47. Suniti Kumar Chatterji, The Origin and Development of Bengali Language, 2 pts. in 3 vols. (1926; repr., Calcutta: George Allen Unwin, 1975), 1:206.

48. In a rather remarkable essay, Giuseppe Flora traces this ambivalence and ambiguity across the late nineteenth to early twentieth centuries; see Flora, On Fairy Tales, Intellectuals and Nationalism in Bengal (1880-1920), Supplement no. 1, Alla Rivista Degli Studi Orientali, vol. 75 (Pisa: Istituti Editoriali e Poligrafici Internazionali, 2002).

49. Āhmad Śarīph, Bāngālī o bānglā sāhitya, vol. 2 (Ḍhākā: Bānnglā Ekāḍemī, 1390 вs [1983]); see esp. chap. 17. While there is no question that part of the mission of the Bangla Academy in Dhaka was to ensure a new Bangla literary world that included Muslim authors alongside Hindu and secular, it is perhaps notable that Ahmad Sharif was a self-described Marxist (personal communication, Dhaka, June 20, 1988).

50. Muhammad Śahīdullāh, Bānglā sāhityer kathā, in Śahīdullāh racanābalī, ed. Ānisujjāmān, 3 vols. (Ḍhākā: Bāṃlā Ekāọemīi, 1994), 2:1-504.

51. Abdul Karim, A Social History of the Muslims of Bengal, down to A.D. 1538 (Dacca: The Asiatic Society of Pakistan, 1959). See also the pioneering sourcebook: A Descriptive Catalogue of the Bengali Manuscripts in Munshi Abdul Karim's Collection, comp. Munshi Abdul Karim and Ahmad Sharif (Dacca: The Asiatic Society of Pakistan, 1964). Karim identified numerous works of previously unknown musalmāni poets.

52. Muhammad Enamul Haq, Muhammad enāmul hak racanāvalī, ed. Mansur Musā, 5 vols. (Ḍhākā: Bāṃlā Ekāẹemī, 1398-1404 Bs [ca. 1991-1997)]).

53. Halder, "Of Blood and Tears"; this is one of the central theses of Halder's dissertation. 
an archive for manuscripts and for the mass-produced cheap print literature (bat talā). ${ }^{54}$ Recently, Ābdul Khāyer Sekh completed a dissertation on this popular puthi or püthi literature of the nineteenth and twentieth centuries, which surveys more than three hundred sixty such discrete texts. ${ }^{55}$ Once widely popular, then repudiated in the face of criticism by the reformers and elites involved in the discovery of the vast Bangla literary heritage (without, however, losing their rural popularity), the texts had come full circle: the Bengali Muslim experience and identity of modern Bengal was captured in the sum of its distinctly religious narratives composed in the earlier musalmāni bānglā, reinstating the folk literatures that were the staple of the musalmāni population that was largely agrarian. And it is true, just as their critics pronounced, the tales are incredibly entertaining, but that entertainment value is not silliness or slapstick (though one will occasionally run across a vignette that would qualify, especially when the animals talk); rather, the humor likes to turn the-world-as-it-is-known on its head, raising an eyebrow at the pretensions of those in power, poking fun at hallowed institutions, indeed challenging even the gods.

We can identify fairly clearly many of the attitudes that contributed to the previous elimination from the official canons of Bangla literature and culture. But even these much-needed interventions do not address the question of the texts' raison d'être, their utility as religious and literary productions. Just what kind of cultural and religious work have these texts done, and have continued to do, that allowed them to thrive for centuries essentially unchanged? How have these texts managed to construct coherent worlds of meaning where hinduyāni and musalmāni characters share a common perspective? And what does it mean that they do? These and related questions will animate the remainder of this inquiry.

\subsection{A PREGNANT AMBIGUITY}

The story of Satya Pīr's birth at the beginning of this chapter provides some clues that can serve as a starting point for our investigation of the cultural work shouldered by these tales of pìrs and bibīs. As we have already seen, Satya Pīr's birth was anything but ordinary, and when things are out of the ordinary, there is often some hidden significance-the uncanny and marvelous are seldom gratuitous. When we talk of cultural work, we are not trying to articulate some goal-oriented agenda

54. Though he did not deem bat talā publications worthy of inclusion in his influential Bānglā sāhityer itihās, Sukumār Sen did write several short essays on these publications, mostly compilations of titles, illustrations, and presses; significantly he identified in excess of three hundred such publishers and printers. The essays were subsequently collected into a single volume by his son Subhadrakumār Sen. See Sukumār Sen, Baț talār chāpā o chabi, comp./ed. Subhadrakumār Sen, 1984; 2nd. ed. 2008 (repr., Kalakātā: Ānand Pāblišārs Prāibheț Limițeḍ, 2015).

55. Ābdul Khāyer Sekh, “'Musalmānī’ pũthi sāhitya: Anusandhān o parjālocanā” (PhD diss., Calcutta University, 2015). 
(which would, as we shall soon see, remove a text from the realm of the literary and relocate it in religious or political propaganda). Rather, I am keen to trace and explore the contours of these imaginative worlds, the world as these authors envisioned it might or could be. We can surmise that the rootedness of the text of Bada satya pīr o sandhyāvatī kanyār puthi in Bangla, with its setting in Bengal, would signal that the explorations are of local import-but the nature of that import may not be self-evident. Though this text and others depict an unusual, if not on occasion seemingly outlandish, cosmology according to accepted sectarian and even scientific standards today, I will argue that this represents a predictable exploration of possibilities that occur when the-world-as-we-know-it somehow seems unstable, shifting in directions that give one pause-the tenor of these stories is one of uncertainty in changing times. This is not to propose a direct causal connection, that every time the cultural climate shifts, fantastic tales ensue; rather, it is a particular response to a particular historical situation wherein a number of competing factions were laying claim to authority, often with no clear-cut arbiter of cultural standards, prompting exploration of alternatives. The alternatives carry with them concomitant shifts in moral sensibilities. This was the case in Bengal, especially from the fourteenth to the nineteenth centuries, a region rife with political strain from the shift from Sultanate to Mughal to colonial rule, and the constant influx of foreigners, many of whom brought a new vision of the world from across the seas. Pìr kathās emerge as culturally significant literary productions during these times of transition. So let us go back to our initial story of the birth of Satya Pīr and see how the author ruptures the expectations of the normal order of things and what some of the implications may be.

In Kṛ̣̣ṇahari Dās's opening, the conversation between Mohāmmad and Āllā centers on the need to send an "avatār for the Kali Age." This trope spins out of the classical vaiṣnav construct of the yugāvatār or descent for the Age, which by the fifteenth century was a commonplace all across North India to indicate the need for the presence of God or some form of the divine to correct human excesses, to establish new forms of ritual practices that would be easier and more efficacious, and settle the world's uneasiness. Because of the obviousness and universality of the mechanism, no explanation is required for this religiously generic proposition: when the good of the world is under duress, God's intervention is required to reset the course of order. In this opening scene, Mohāmmad indicates that the form and the message will be different, which fits perfectly with the vaiṣav notion that each time God has to descend or send a celestial figure to earth, the remedy is novel to the situation, commensurate to the nature of the need. Mohāmmad makes clear that the way this avatār will differ from prior avatārs is his target audience: the single figure of Satya Pīr will serve a dual purpose by taking a dual form, appearing as Satya Nārāyaṇ to hinduyāni and as Satya Pīr to musalmāni constituencies. The dual form recognizes there are differences among the various communities, but its single source implies that the differences are superficial. With this approach, we 
should be wary of attributing contemporary notions of "identity" as most people tend to think of it today in a post-Enlightenment mode, and even more so as it informs contemporary "identity politics" in the subcontinent. When it does begin to skew in that direction-as is hinted in the late-arriving figure of Bonbibi- the stakes are quite different from the overt posturing we associate with the present categories of Hindu and Muslim in identity politics. So how might we interpret this action?

Theologically, there is no argument: the opening simply declares that there is only one God, Āllā, who will assume a dual form as Satya Nārāyaṇ (normally associated with the god Viṣnu) and Satya Pīr (often assumed to be no more than a saint, though in this case Âllā explicitly declares that He Himself would take on this form, yet in the narrative Satya Pīr is mysteriously separate from him). The assertion of this ontology, which appears to be based on the widespread sūph $\bar{\imath}$ theological perspective of the unity of God (what could be technically construed as wahdat al-wujūd) subtly underscores the Islamic leanings of the text, but no argument is made, no authority cited, and technical terminology (such as the Arabic phrase noted above) is absent-and this absence of Arabic or Persian technical jargon is an important feature of this and similar texts to which we will have occasion to return. So we must ask: if the text is not arguing for the identity of Viṣnu and Âllā, but simply assumes it, what is the fuss about Satya Pīr assuming a dual form? In a statement that is repeated by different characters, Kṛṣnahari Dās notes that dual form is an expedient device to ensure that the avatār for the Kali Age is heard: it is one's social standing, ritual orientation, modes of marriage alliance, and differences in commensal restrictions that distinguish people, one from another. This avatār for the Kali Age will not simply address the different communities in image or appearance, but will actualize the non-difference among them by quite literally taking birth in multiple communities $(k u l)$, but in the same form. So how does he do this if he is born of Sandhyāvatī?

Mohāmmad has designated the færie Cāndbibī to become Satya Pīr's mother, but Cāndbibì is already safely resident in heaven, bhest. She will have to descend to prepare the way, to be born of the queen Priyāvati in the demonic brāhman king Maidānav's household. Before her rebirth, Cāndbibī herself wonders how she can be born a jäbanā, that is, a female musalmān, from that parentage. Satya Pīr's mother-Cāndbibī as Sandhyāvatī-is, then, of mixed descent in this worldly birth, or so it would seem, except that she claims to retain her designation, that is, she self-identifies as a jābana $\bar{a}$, which is not mixed at all. This is perhaps the first real indicator of what is at stake in this story, for apparently in our author's view, birth from a brāhman womb does not necessarily produce a hinduyāni child, in spite of the several thousand years of conditioning in South Asia regarding the nature of genealogy and birth. Does Sandhyāvatī, formerly the jābanā Cāndbibī, appear to be anything other than a brāhman princess? Already, long before the arrival of Satya Pìr, the boundaries between the various communities begin to 
dissolve. But whether Sandhyāvatī is both a jābanā and a brāhman seems moot when she finally gives birth. Satya Pìr seems to be signaling that the distinctions of social rank are artificial.

Sandhyāvatī gives birth, not to a child, but to a quivering mass of coagulating blood. She is understandably distraught, but assessing the situation with a kind of cool calculation-much as she did when confronted with the frog firmly gripped in the jaws of the serpent and pleading for its life-she reasons her way to a course of action. She takes the congealed mass and hurls it into the waters of the Begavatī River, just as she returned the frog to its natural habitat after prying it away from the jaws of the snake. On the one hand, it would appear that she has further compounded her serpent-killing offense in heaven, which damned her to thirty-six years on earth as a mortal. And remember, the author, Kṛṣnahari Dās, in his descriptions of human action with respect to heaven and hell, observes that committing an offense (aparädh) in heaven sends one to earth, while doing the same on earth sends one to hell. One cannot but wonder how many more lives she will have to suffer for discarding the mass that was to be her son. The author is at pains, however, to note that individuals have predictable inescapable tendencies, so what they have done is what they are likely to repeat in the future-and here Cāndbibī seems to have been specially chosen to effect God's larger plan.

The frog that she liberates to the waters of the river was to be food for the snake, its release an apparent act of compassion for the animal that first appealed to her for mercy (the snake could only counter), so in spite of the karmic effect of her decision leading to the death of the serpent, there is some positive result in the rescue of the frog. In a curious inversion of her previous act, when she throws the oozing mass of preformed Satya Pìr-more of an embryonic mass rather than a fetus, based on the description, and not obviously alive-that splodgy mess becomes food for a turtle lurking in the waters of the Begavatī River. The potentially negative act inverts her action with the snake and frog with a positive result, though the author does not indicate that that was her intention. By turning the bloody mass into apparent food, Satya Pìr is rescued by the turtle, perhaps ameliorating what could well have been Sandhyāvatî’s undoing. The turtle instantly gobbles up the mass, swallows it, and encases it in an egg, gestating it for ten watches (one watch, or danda, is calculated as twenty-four minutes). She lays the egg into the sands of a shoal, whence Satya Pìr emerges fully formed. As a result of that hatching, the turtle becomes his second mother, so at first blush it would seem that one of the communities Satya Pir will be addressing is the animal kingdom, or at least the riverine ecology. But that turtle is not just any turtle; she has previously been a brähman widow who was cursed to live as a turtle for the offense of eating the uncooked meat of a cow. In a predictable repetition of her previous act, she has just consumed the raw meat of the embryonic Satya Nārāyan (who will eventually take on the form of a human, but whose ontological status is actually none other than God, Âllā). In this karmic economy, the turtle is granted a major reprieve 
of her sentence, with the promise that she will bear none other than God in her womb. As soon as she has fulfilled this duty by birthing Satya Nārāyaṇ, she will fly off to heaven, then called by the vaiṣnav name of vaikuntha-and that is precisely what happens. This, then, is the avatār's second birth, ironically (perhaps?) literally making him twice-born, with one mixed jābanā-brähman mother and one brāhman widow mother, each of whom in her own way abandons or orphans the fatherless Satya Pīr, leaving him to his own devices. The narrative sequence seems to suggest that the former brāhman widow has rescued the jābanā mother from further perdition by virtue of completing her pregnancy, but because of the nature of the birth-Satya Nārāyan emerging from the egg buried in the sands-he not only comes from the wombs of two mothers of competing social status, but bears the marks of a chthonic hero, born of Mother Earth, Prithivī, as invoked in the author's opening. ${ }^{56}$

The familiar old saw that declares certainty of motherhood, but obscurity regarding the father, holds strangely in spite of the inversion that sees one offspring from many wombs rather than many offspring from a single womb, for each time, the identity and social standing of the mother is made clear. But most immediately for the narrative plot, Sandhyāvati presents a problem, for in the eyes of her servants, her mother, and her father, she is very clearly pregnant (hence the mother), but unmarried, and therefore prima facie guilty of a premarital affair and about to issue a bastard. She of course protests her innocence, but no one else can know or believe that she is a virgin. Only she knows for certain that she has never even lain with a man; but who can believe that in the face of her pregnancy? Poignantly, the inchoate bloody mass to which she gives birth seems to beg the question, as she herself notes with bitter irony:

I was born on earth to provide a womb, but I have not given birth to a son. This "child" has no eyes, no mouth, no arms, no legs. Concealed in my womb, it grew inside me for ten months. It left me indelibly stained for all the world and forced me to live abandoned in the forest. There is no father to come forward to acknowledge, for he could not acknowledge truthfully this rubbish born of my womb. Why has Fate, Bidhātā, written my karma this way, that I must live lost, deep in the forest, and for what? For whom?57

56. Mircea Eliade argued that in the case of chthonic cultural heroes, the Earth was the mother, and the remote Sky God the father. There is a strong resonance here because Âllā in heaven impregnates Sandhyāvati via the rose, then she in turn, by inadvertently feeding the turtle, impregnates the turtle, who deposits the egg in the womb of Mother Earth, Pṛthvī, from whom Satya Pīr/Nārāyan emerges fully formed. See Eliade, Patterns in Comparative Religion (1958; repr., New York: New American Library, 1963), 239-64. The mythic motif of the relay is also frequently noted by Eliade in a number of publications.

57. Kṛ̣nạahari Dās, Bạ̣a satya pīr o sandhyāvatī kanyār puthi, 33 . 
The reader of this text will, of course, have the advantage of knowing what Sandhyāvatī cannot yet know, that her apparent stillbirth is actually Satya Pìr. She is understandably confused by the commonly noted amnesia that occurs when heavenly figures undergo birth in the world of mortals; she does not know who she "really" is. Prior to her birth on earth, she in fact astutely appraised the situation as singular-a jäbanā born of a musalmān-killing king's wife-what we might imagine to be something akin to an existential crisis, except-as is often repeated in Indic tales-that she is oblivious to it once she has descended. She then questions the clarity of the instructions she received in the dream sequence, which impelled her to go to the river and refuse to leave until she retrieved just the right flower, since the result of that simple gesture of smelling the flower has proved so wrongfully fateful. Upon reflection, she is able to identify the precise moment of conception, but questions neither the method nor who is responsible. She feels mysteriously used, but to no end she can fathom. She observes, as many other narrators have routinely observed, "Who can know God's mysterious ways?" though the audience does already know.

While the audience for this story would be comfortable in the knowledge of Satya Pìr's descent from heaven, the question of his paternity remains obscure and hangs over the entirety of the Sandhyāvatī sequence of episodes. Is it God? Does divine insemination through the fragrance of a flower count as fathering? But Satya Pīr is already a fully formed, functional adult saint passing his time in the heavenly paradise of bhest before the descent, and he even observes that this will not be the first time he experiences existence on earth, his previous exploits having earned him that coveted place in heaven. So who, then, are his mother and father? Does it matter? Perhaps more importantly, one might not unreasonably ask how, precisely, a mortal (and to become a saint, one must presume that at some point Satya Pīr was mortal) can be reborn on earth. The operations of karma and rebirth, in fact, are commonly accepted in this text, for we may recall that the færie Cāndbibī herself argues that only by committing great offenses (aparādh) can one be reborn on earth. But Fate in the form of the god Bidhātā is also inextricably connected, and therefore blamed as well. From the references to reaping the fruits of karma and the characterization of the age being one of degradation, the Kali Age, the cosmology seems marked as a traditional Indic, and specifically Bengali, cultural view.

In the end, Satya Pīr, who is a recognized saint—one of the "friends of God," as they are known ${ }^{58}$ - descends from heaven as the avatār of the Kali Age and is born directly from God's impregnation of an unmarried musalmāni færie in the form of a virgin girl born of a brāhman queen, and then born a second time from a turtle mother who is a cursed unmarried brāhman widow (both births magnifying Satya

58. See John Renard, Friends of God: Islamic Images of Piety, Commitment, and Servanthood (Berkeley: University of California Press, 2008). 
Pīr's status as a twice-born (a twice-born twice-born!), yet from the perspective of those around him, twice a bastard, perhaps a not-so-subtle commentary on the "high esteem" in which brāhmaṇs are held. Earlier in bhest, Āllā told Mohāmmad that He Himself would descend, while the unnamed turtle reported that she too was to bear God, Satya Nārāyaṇ or Nirañjan, not just a saint. The quivering mass to which Sandhyāvati gives birth is described in terms that hint of the famous passage in the Śvetāśvatāra Upaniṣad of the ultimate reality of brahman (n) assuming the characteristics of God, "grasping without hands, moving without feet, seeing without eyes, hearing without ears . . " ${ }_{59}$ If Satya Pīr is this ultimate reality as God, what of the paternity of Satya Pìr via the turtle mother? It would seem to be God working through Cāndbibī herself who impregnates the turtle, suggesting a transsexual paternity, which in turn conflates with gender the already-prophesied birth for two communities. That sequence at least raises the possibility that fathering is instrumental, that it is as much enacted as gendered; and in a karmic economy, gender is always situational because one may well have been another gender in a previous existence, which undercuts claims to blood lineage as the primary marker of identity. The multitude of ambiguities of parentage and genealogy for Satya Pīr cannot be insignificant. Satya Pīr's dual form is not simply an appearance, but the result of his multiple births from women of different social groups $(k u l)$, quite literally embodying the boundary-crossing his dual form was intended to address. He rises from within the ranks of those different groups, intent on appearing in whatever form is needed and appropriate to his followers. Here we get one of the first cogent statements of the future work of Satya Pìr: he ministers to the needs of everyone, regardless of social standing-birth does not matter. Importantly, he is of mixed parentage, born first of an unmarried jabanā-brähman woman and then from a brāhman widow, both of whom abandon him immediately after birth, leaving him twice orphaned. This avatār for the age knows firsthand whereof he speaks and makes clear the object of his later ministrations. As the author Kṛ̣nahari Dās notes in his opening salutations:

... Satya Pìr comes to those who call, whether orphans without means or those devoid of guidance. Should all people present sing their praises publicly, Satya Pìr will send their troubles far away. When people serve him with respect, offering the custom due, Satya Pir becomes the refuge of every human being. ${ }^{60}$

What the Lord Nirañjan—as Satya Pīr and as Satya Nārāyaṇ-offers is not dependent on birth or social distinction, nor does it hinge on any sectarian or doctrinal

59. Śvetāśvatāra Upaniṣad, trans. Robert Ernest Hume, 3.19: apānipādo javano grahītā paśyatyacakṣuh sa śnotyakarṇah... in Thirteen Principal Upaniṣads: Original Sanskrit Text with English Translation, trans. Hume, ed. N.C. Panda, rev. ed., vol. 2 (New Delhi: Bharatiya Kala Prakashan, 2012).

6o. Kṛ̣ṇahari Dās, Baḍa satya pīr o sandhyāvatī kanyār puthi, 4. 
stance: one need only respectfully petition God (regardless of form) to receive his aid. That in turn suggests that conversion per se is decidedly not at stake; God's good will and assistance is available to everyone regardless and is not affected by the various social strictures that are observed in Bengal's social world. Even offenses that center on food regimes, diet, and commensality do not stop one from successfully serving as an instrument of God's plan and, in the end, prove no bar to entering (in the case of the brähman widow-cum-turtle) or reentering heaven (in the case of Cāndbibī-cum-Sandhyāvatī), whether that heaven is designated as vaikuntha or bhest. And calling bhest by the vaiṣnav name vaikuntha would seem to be perfectly appropriate, for the etymology of vaikuntha signals a place where people are devoid or separated from ( $v i$-) their ignorance and anxiety (kuntha), so people who worship God in whatever form find that as their reward. The breaking down of social distinctions and the futility of maintaining strict genealogical, commensal, and ritual purity will surface again and again as the first line of instruction in the vade mecum for personal conduct to allow access to Satya Pìr's helping hand. In laying out his divine plan of action, Āllā puts one final stipulation on Satya Pīr's descent as avatär: he will never be allowed to marry. Now it becomes clear why: for him to marry would perpetuate the social distinctions his dual form is designed to undermine-he must not choose sides and father children who would potentially recreate the distinctions he is attempting to efface. Why this is critical will become ever more apparent as we work our way through these cycles of adventure. 